\title{
Introduction
}

\author{
"That Acre of Ground"
}

Can a subject be sovereign in conditions of hegemony? Can forces of hegemony and empire suffocate creativity? This book is about "that acre of ground" over which empire could not have jurisdiction, that ground which cannot be taken from us, not even by the most empowered oppressor. The phrase is Caribbean writer George Lamming's, who uses it to evoke the location within him that remains ever generative through displacements. ${ }^{1}$ I call on that phrase for the specific resonance it has with this book on the figure of the audacious raconteur in colonial India, a figure who not only flourished in colonial India but also can be found thriving in any time or place where there is systematized oppression or othering. In an interview with the anthropologist (and fellow West Indian) David Scott, Lamming elaborates on that acre of ground: "It is inexhaustible, and the one thing that one could not bear to lose and go on breathing would be that acre- that is to be held on to. And that is what I mean, too, when I say that no limitation of sovereignty in the political sense can alter that, because that acre is also itself a component of the imagination." 2

\section{The Backstory}

In 1617 Thomas Roe, an emissary of King James 1 of England, stepped into the resplendent court of the Mughal emperor Jahangir in Delhi. He 
had come to plead on behalf of a chartered joint-stock English company, the East India Company, for permission to trade. The Company had already been trading in India since 1611 out of the port town of Masulipatnam (now Machilipatnam) on the southeastern coast of India. On this coastline, known as the Coromandel Coast, which bustled with spice and textile markets, the English vied with French and Dutch traders. The Company had also been trading on the west coast of India out of Surat (in modern Gujarat). These settlements, however, were small; the British, fully aware of the potential of trading with India, wanted to expand their base. Roe knew, as did the English Parliament, that he had stepped into the court of the richest empire in the world; India at that time commanded about 25 percent of the world's GDP in contrast to Britain's 2 percent. Jahangir, for his part, saw an opportunity to curb Portuguese power on the western coast of his empire and so gave Roe his permission to set up trading posts in Surat and, shortly afterwards, in Hugli (in Bengal) on the eastern coast. The goods traded and the trading routes tell another sordid story. For instance, saltpeter used in gunpowder went to England; opium, which the Company grew in India, went east to China to pay for Chinese tea and porcelain. ${ }^{3}$ Jahangir's permission changed India's destiny forever. As Mughal power began to wane in the late seventeenth century, the Company built up its own armies, at first with the declared intent to protect its warehouses ("factories"), and then to expand its zones of trade. By 1700 the Company had engaged in military conflict with the Mughal ruler and had established fortified settlements in the key ports of Madras, Calcutta, and Bombay. These settlements would later become capital cities of the "presidencies," the political zones of British India.

Over the next two centuries, the Company grew rapidly, often exploiting tensions between competing powers-the Mughals, the Marathas, the nawabs of Awadh and Bengal, and the French in India. The year 1764 was especially pivotal. In the battle of Buxar, Company officer Robert Clive defeated the combined forces of the weakened Mughals, and the Mughal emperor was forced to grant the Company the diwani, the right to collect tax from the provinces of Bengal, Bihar, and Orissa. The nawab of Bengal, who controlled these extraordinarily wealthy provinces, remained the administrative head, but the Company appointed itself his "revenue minister." Brazen looting, territorial expansion, and overseas deposits rather than local investment fueled the Company's growth. Rampant corruption raked in fortunes for the Company's officers, who became known as "nabobs"; from just the spoils of wars, Clive transferred hundreds of millions of pounds to the Company and himself made millions of pounds. Stories of the rapacity of Company officers reached the English public, and the Company's directors, in response to 


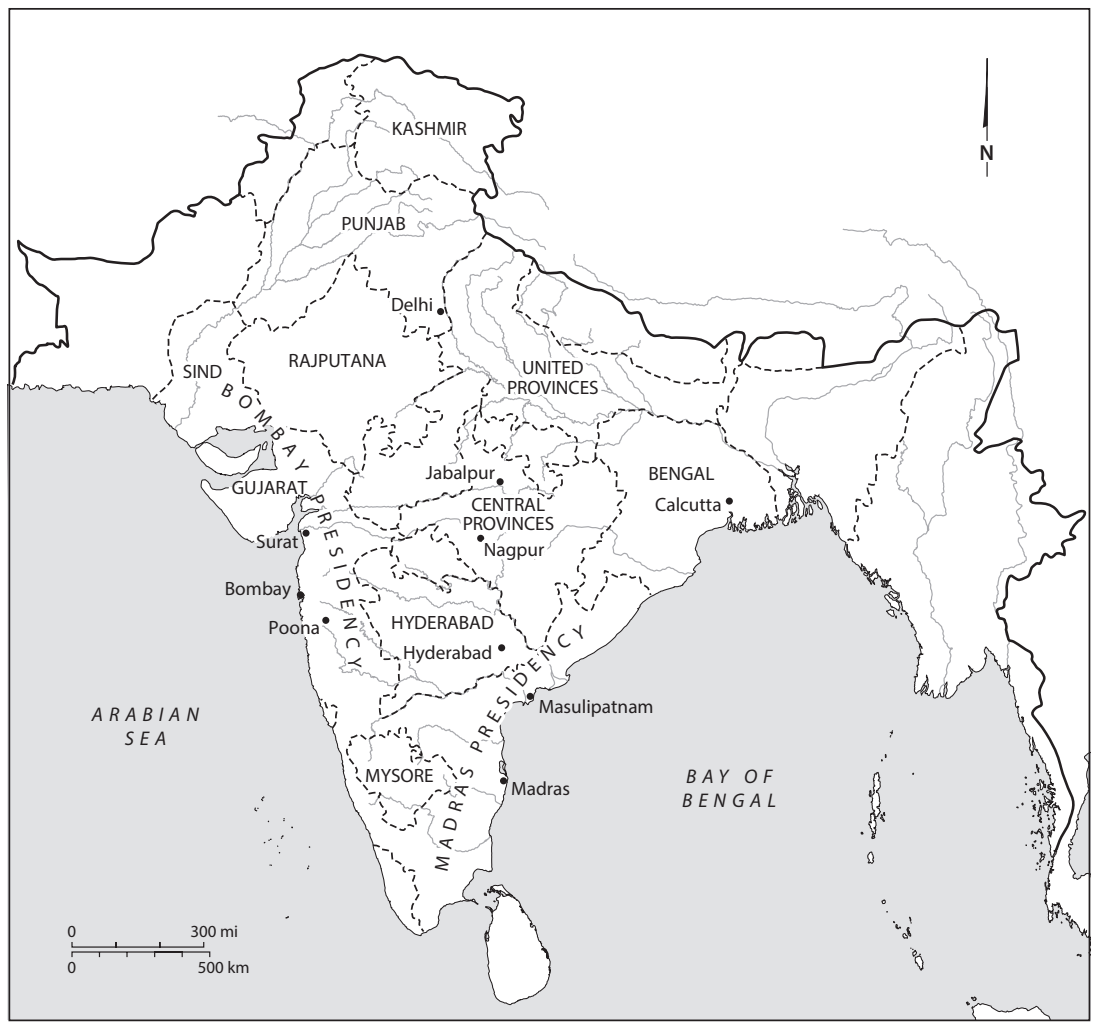

MAP 1. India with presidencies, 1880

Source: Map by Bill Nelson. Based on information from G. U. Pope, Text-book of Indian History (London: W. H. Allen \& Co., 1880).

public opinion, appointed in 1772 a "governor-general" who would oversee the governance of its Indian territories. The gleam of personal wealth was no less a reason for this shift in administration. This new system of governorsgeneral and its official infrastructure sanctioned a rule of bloody conquest. Princely territories were ruthlessly annexed, draconian laws were drawn up, and India's wealth was steadily siphoned off. After the Indian Uprising of 1857-58, when the Company received its first jolt, direct "Crown rule" replaced Company rule. India became the most prized of Britain's colonies. ${ }^{4}$

\section{Mapping India}

Indeed, by the 1880 s, the British had come to believe that their empire was at its summit. Most of India had been colonized and surveyed. ${ }^{5}$ Beyond the northern rim of India, the sacred and ancient Himalayan peak Chomol- 
ungma, also known as Sagarmatha, had been measured and renamed Mount Everest after an Englishman. ${ }^{6}$ Imperial and provincial gazetteers and census handbooks described and catalogued nearly every corner and community. Ancient Sanskrit and Pali texts were translated into English. Languages and laws were codified. Those who advocated for European knowledge as the best means to educate Indians triumphantly imagined that Indian universities and colleges had successfully produced a surplus of brown clerks, the cogs of the wheels of a colonial administration. The field of anthropology began to conceive itself as a "science" and a "discipline," and professional societies such as the Royal Anthropological Institute (1871) and the FolkLore Society (1878) now stamped as bona fide the collection and publication of knowledge about Indian culture. ${ }^{7}$

Despite all this mapping, renaming, and claiming, where in the cavernous hollow of empire could one find everyday India? This question became peculiarly urgent to the missions of the empire and the Church of England. It also created a lucrative marketplace for Indian exotica. Stories, songs, and proverbs recorded from the "lips of natives" promised to reveal a quotidian India different from the India of maps and ancient texts and political conquests. A pioneer in this quest was Mary Frere, daughter of the governor of Bombay Presidency, who asked her Indian ayah, Anna Liberata de Souza, to tell stories while they traveled together through south India. She sent the first few stories to her sister in England, her letters transmitting an India animated by princesses, cobras, jungles, and more. Recording more stories, she published Old Deccan Days, or, Hindoo Fairy Legends Current in Southern India in 1868, and enlivened the collection by including Anna's life story. "Will no one go to the diggings?" Frere asked, echoing an antiquarian interest. ${ }^{8}$ Frere seems to have appealed to a motley group of British colonial administrators, their daughters and wives, and Christian missionaries, who began to publish "Indian folklore."

And so there emerged, between 1865 and 1930, a staggering number of collections of Indian lore from presses in London, Calcutta, Bombay, and Madras (today Kolkata, Mumbai, and Chennai). But this world of fascinating stories is also haunted. It is haunted by the footnoted voices of barely acknowledged storytellers and assistants, by coercive collecting methods, by disparaging commentary, and by drastic alterations to texts. ${ }^{10}$ Captain Richard C. Temple, for example, "induced" stories, to use his word, by heavily doping the bards who fill his three-volume Legends of the Punjab, while Flora Annie Steel called Indian narrators "wild beasts" who were prone to "stampede." 11 The story of a text called Qanoon-e-Islam, or, Customs of the Moosulmans illustrates how texts were distorted. As Sylvia Vatuk shows, this text was written in Hyderabad in the Deccan by a scholar and Unani physician, Ja'far 
Sharif, at the behest of Gerhard Herklots, a British army surgeon. Originally published in 1832, Sharif's Qanoon-e-Islam was a descriptive account of the customs and practices of Muslims of the Deccan. Herklots translated and annotated Sharif's text for English audiences. In 1863, when Higginbothams of Madras republished it, it was massively generalized and called a standard text of "Indo-Mahomedan" practices. And in 1921 the administrator William Crooke completely altered the original and published it as Islam in India, a "new" text that was far removed from Sharif's Qanoon-e-Islam. ${ }^{12}$

Lines of transmission of stories within British publishing circuits resulted in heavily doctored texts. British authors borrowed Indian cultural material from one another through published and unpublished sources. The preface of W. H. D Rouse's volume The Talking Thrush and Other Tales from India (1922) tells us that the stories were part of a larger ethnological survey undertaken by Crooke in the (then) Northwest Provinces and Avadh:

Some [stories] were recorded by the collector from the lips of the jungle-folk of Mirzapur; others by [Crooke's] native assistant, Pandit Ramgharib Chaube. Besides these, a large number were received from all parts of the Provinces in response to a circular issued by Mr. J. C. Nesfield, the Director of Public Instruction, to all teachers of village schools.... In the re-telling, for which Mr. Rouse is responsible, a number of changes have been made. ${ }^{13}$

Finally, the word "collection" itself was an open category that froze contemporary lived traditions into the tenets of ancient texts. Many "collectors" collated stories from well-known written corpuses without consulting living oral sources at all. ${ }^{14}$ The missionary Charles E. Gover compiled and translated Tamil, Telugu, Kannada, and Malayalam songs from various textual sources (about which he is vague), calling his collection The Folk-songs of Southern India (1871). The orientalist Forster Arbuthnot, writing under the disingenuous pseudonym "Anaryan," compiled stories from a variety of Sanskrit collections, drawing mostly on the translations of other well-known orientalist scholars like William Jones, H. T. Colebrooke, Henry H. Wilson, and Max Muller. Extended extracts from Vatsyayana's Kama Sutra (second or third century CE) are seamlessly used in the introduction and the conclusion to illustrate the contemporary "social domestic economy of the Hindoos." 15

\section{My Search}

About twenty-five years ago, I chanced upon Mary Frere's Old Deccan Days in a library in the American Midwest. Its many voices gripped me, enticing 
me to the field of colonial folklore collection and ethnography. The tracks in this field led me through libraries and archives and gravesites and abandoned buildings across India, England, and America. I sifted through thousands of pages of correspondence in publishers' archives, manuscripts of collections, minutes of professional societies, letters, photographs, and miscellaneous lists from colonial India and many standalone Indian publications. In the Folklore Society's archives in University College London, for instance, I read a manuscript titled "A Folktale of Kumaon" in the calligraphic handwriting of Pandit Bhagwan Das Sharma, who had written down the story when he stopped at a stage bungalow near the village of Bans in the foothills of the Himalayas. ${ }^{16}$ In the University of Reading's publisher archives, I read the exasperated letters that Dwijendra Nath Neogi wrote to Macmillan protesting the miscalculation of royalties on his books Sacred Tales of India (1916) and True Tales of Indian Life (1917). ${ }^{17}$ The faces and voices of Indian authorship began to intrigue me.

Of course, ethnography in colonial India was not just a British enterprise. It is true, as I have noted, that many Indians_-bards, servants, clerks, munshis (interpreter or secretary), pandits, and general village folk-appear namelessly or facelessly as "old native storytellers" in the margins and footnotes of British-authored collections. But Indian scholars, writers, schoolteachers, and lawyers also published independent collections of stories, monographs on customs and traditions, and translations and adaptations of Sanskrit and regional literatures. Some Indian-authored collections ostensibly reflect little difference in tone and method from British-authored collections. For instance, the Reverend Lal Behari Day, in his Folk-Tales of Bengal (1883), says:

After a great deal of search, I found my Gammer Grethel-though not half so old as the Frau Viehmännin of Hesse-Cassel—in the person of a Bengali Christian woman, who, when a little girl and living in her heathen home, had heard many stories from her old grandmother. She was a good story-teller, but her stock was not large; and after I had heard ten from her I had to look about for fresh sources. An old Brahman told me two stories; an old barber, three; an old servant of mine told me two; and the rest I heard from another old Brahman. ${ }^{18}$

Other collectors like Ganeshji Jethabhai, a lawyer from the peninsula of Kathiawar (in modern Gujarat), extracted and polished ninety-four stories from unspecified "local chronicles" and published this collection in Gujarati in 1885 for school use. He had the book translated into English in 1903 as Indian Folklore; the book promptly drew strong negative remarks from British reviewers for its "unscientific" methods. ${ }^{19}$ Under the same title, Ram Satya 
Mukharji, a government official in Tamluk (Bengal), published stories in 1904 that he remembered from his childhood. ${ }^{20}$ Some other collectors had a literary bent. For instance, Shovona Devi, Rabindranath Tagore's niece, published twenty-eight stories in her collection The Orient Pearls: Indian Folklore (1915). These stories exude the aura of Tagore's short stories about Bengali rural life, but they also reflect Shovona Devi's upbringing in an upper-class English-educated Hindu household, which employed long-term domestic caretakers who told her stories.

But it is a different kind of Indian presence that I write about in this book. This remarkable presence, which has altogether escaped notice, is not of an Indian narrating stories in confined and controlled spaces, or of an Indian writing in conformity to European norms. On the contrary, the Indian figure I discovered is a zesty raconteur in the public square, full of life, audaciously challenging the ideological bulwark of colonialism. I use the word "raconteur" to recognize the art of narration that storytellers in colonial India consciously commanded. The "audacious raconteur" is also a riposte to the pejorative colonial construct of "old native storyteller." I argue that even the most hegemonic circumstances cannot suppress the "audacious raconteur," a skilled narrator who sometimes uses the idioms of the dominant to point to a narrative space that, while seeming to be entwined with the dominant, in fact remains sovereign and beyond subjugation.

\section{The Raconteurs}

Four raconteurs from southern India anchor the argument of this book: Anna Liberata de Souza, an ayah who narrated stories to the English daughter of the governor of Bombay; P. V. Ramaswami Raju, a Londontrained, Madras-based Indian lawyer and literary scholar who published stories and plays in English, Tamil, and Sanskrit; M. N. Venkataswami, a librarian in the Muslim state of Hyderabad who wrote exclusively in English about his community's stories and traditions; and S. M. Natesa Sastri, an epigraphist employed by the British government of India, a prolific writer in many genres.

To begin with, the unexplored archive of these raconteurs tells us that their awareness of colonial history, English social etiquette, or Western narrative genres enables them to challenge concepts and conceits central to colonial rule and rhetoric - Western modernity, history, science, and native knowledge. At times they used the very language, genres, and Enlightenment paradigms of the West to re-present concepts of religion, culture, and history through their experiential understandings of those concepts. 
To this extent we can say that the archive is ironic: it embraces norms of colonial knowledge production while modifying or flouting them. The English language itself becomes a tool for play and for protest, not insignificant considering that by the 1880s, English had become established in India as a powerful language of education, public discourse, societal class, and literary exposition. Here we might say is the reverse of the colonial mimicry that the literary critic Homi Bhabha posits. Bhabha argues that the colonizer and colonial discourse operate through a "metonymy of presence," by which the colonizer refigures the colonized as "almost the same but not white" or "almost but not quite." This almost-ness, however, reveals the ambivalence of colonial discourse because this discourse must concede that what is also present in colonial subjection is the "menace" posed by the colonized. ${ }^{21}$ In relation to Bhabha's argument, the "not quite" space is the very space through which the raconteurs of this book demonstrate their sovereignty. Anglophonic terms and technologies camouflage a mastery over Indian ways of knowing, creating, remembering, and being; they take us past the menacing subject to the unsubjugable person-whose sovereignty over the territory of self, culture, and art is unassailable. I elaborate on this idea of sovereignty later in this introduction.

This archive of the raconteurs brings to mind James Scott's analysis of power-stratified interactions, in which the "hidden transcript" is "a critique of power spoken behind the back of the dominant" by the subordinated group. ${ }^{22}$ Scott contrasts hidden transcripts with the "public transcript," the openly visible interaction between a dominating group and the subordinated one. In public transcripts, the speech and bodily gestures of the subordinated acquiesce to the discourse of power. Hidden transcripts are to be found offstage in everyday performative arts such as jokes and rumors, gossip and gestures and stories that generally veil authorship and identification. Behind this veil, the subordinated individual drops acquiescence and replaces it with disobedient critique and perhaps even talk of rebellion. Brian Hatcher tells the story of how the nineteenth-century Bengali social reformer and scholar Ishvarchandra Vidyasagar responded to an English school principal who had put his feet on the desk while conversing with Vidyasagar. When the Englishman visited, Vidyasagar reciprocated with the same gesture by placing his shoe-clad feet on the desk. When reprimanded by a supervising Englishman, he feigned surprise. After all, he said, this was etiquette he had learned from the English themselves. This rejoinder, Hatcher points out, drawing on Scott, is "a kind of pantomime that enacts a form of insubordination." 23

The raconteurs in this book, however, do not rely on "hidden transcripts." Their voices are bold and articulate. They speak in public and quasi-public 
spaces - in mainstream publications, governors' mansions, and public service commission hearings. And they field the risks and pay the price of offending an aggressive regime. In these overt settings, they critique the grand claims of colonial policy, interrogate imperial self-aggrandizements, overturn reigning scholarly methods, and refuse denigrating constructs of culture and person. Life would have been far better without colonialism. This outspokenness is achieved through a rambunctious creativity that challenges the fictions of the empire. Lamming understands the nuanced dialectic between the socalled public and the private:

That is when you come to public affairs, about how decisions are going to be made, according to the constraints of resources, constraints of resources which are in conflict with unlimited expectations or the expressions of a limited expectation brought about by the uncritical and sometimes irresponsible promises made by people who are shaping the society, you realize that there is a limited sovereignty there, but a limited sovereignty acknowledged in the public domain does not necessarily demand a limited sovereignty in the power of the self to perceive why you have to limit that sovereignty. In other words, there is a sovereignty that remains intact in spite of the limitations which you must concede about another kind of sovereignty in the public domain. This is an unending process of thinking of how one has always to rework the ways in which one claims and exercises the power and the authority of an individual and subjective perspective. ${ }^{24}$

The genius of the raconteur's creativity is that it performs a critique of power without the raconteur declaring an intent to be audacious. Our reading strategies, grounded in their narrations, however, help us discern their audacity. This book begins with the story of Anna Liberata de Souza, the narrator of the stories in Mary Frere's Old Deccan Days (1868). Anna's life story is known only through "The Narrator's Narrative," which Frere provides in the highly successful book. I was forced to revisit my earlier favorable interpretation of this book after I stumbled on an extraordinary passage in a colonial memoir by an English botanist who described Anna's pitiful economic state a decade after Old Deccan Days had been published. I adapt Michael Polanyi's theory of meaning-making and rely on intuition and cultural commonality to engage in a "sense reading" of the very same manuscript materials. Sensing Anna, I find she was subaltern only in her economic situation. In voice and in spirit, she was creative and bold: she conveyed to Mary, the daughter of the powerful governor of Bombay Presidency, how she believed the British had failed in India-in education, in economics, and in under- 
standing India's vibrant oral culture. In fact, it emerges that Anna de Souza was a prescient critic of the modernity promised by colonialism. A sense reading also holds up the bleak reality that colonial anthropology, with its pretensions to contextualization, ignored the personhood of storytellers. Was "culture," the ostensible raison d'être of colonial anthropology, itself constructed from a fundamental absence of the living person who animates it? A sense reading of Frere's manuscript suggests that the answer is yes.

The Madras-based lawyer P. V. Ramaswami Raju (1852-1897), the second raconteur in this book, challenged the view of the English that India lacked historical consciousness. Coming from a Telugu-speaking family of a landowning caste, he trained as a barrister in London and taught Telugu and Tamil at University College London. A prolific writer, he published plays, essays on religious subjects, fables in English, and social drama and comedies in Tamil and Telugu. For empire-conscious Victorian audiences, Ramaswami Raju's plays seem to offer classic oriental settings with quasi-historical British and Indian characters and plots. Yet, in a masterly way, through wit and irony, these plays construct characterizations that deflate imperial personae and conceits, as exemplified by his 1876 play Lord Likely. Across his writings, we see Ramaswami Raju using what I describe as a double register, a literary strategy that enables him to speak simultaneously in two voices across cultures and sometimes languages, producing meanings that ripple in counter-flowing directions. His dramatic poem in Sanskrit, Srimat Rajangala Mahodyanam, a fictional account of the "rise of the English race and its empire," deftly contains the history of the English within a Hindu cosmos and telos where the progenitor of the English falls from the heaven of Indra, the Hindu king of gods, to his ruin. This artistic move effectively punctures the grandiose idea of "English history," showing it as valued only by British imperial historians.

If the notion of English history falls apart through Ramaswami Raju's writings, the imperial bastion of the scientific method is challenged in the writings of M. N. Venkataswami (1865-1931), who came from the Teluguspeaking caste of Medaras (bamboo weavers) who had settled in Nagpur in central India. Fascinated by an autographed copy of Venkataswami's biography of his father, which I chanced upon in a used book store in London, I procured the lone extant copies of his other writings, all self-published, from various libraries. Reading these self-published books, I realized that I was in the presence of a writer who adopted the scientific method endorsed by colonial anthropology and folklore, but in every way possible he went against its sacrosanct ideal of objectivity. Nineteenth-century Europe, as we know well today, embraced the idea that truth could be secured through 
the scientific method, a method based on experiment, evidence, and classification. The method flourished in overseas anthropology, where it abetted racist theories of civilizational progress and the violence that accompanied the implementation of these theories. And so the colonial anthropology of stories was more like the archaeology of living communities than like rigorous science. It was in his writings, all of which were in English, that Venkataswami exuberantly restored the "subject" to the science of anthropology. Undeterred by his class, caste, and race, he titled many of his books after members of his family; he used new photographic technology to alter family photographs and to provide startling illustrations for his fairy stories; and he used oral stories to counter the so-called objective accounts of imperial historians. I trace how Venkataswami vivifies the human subject in The Story of Bobbili and in his biography of his father, Life of M. Nagloo. He powerfully asserts- through techniques that I collectively term the "subjective lens"- that at the heart of anthropology and history is not some rarefied notion of objectivity but prismatic subjective truths that come from everyday experience.

Without the "native scholar," the shelves of oriental and folklore scholarship would have been empty, and colonial governance would not have comprehended Indian texts and practices. Colonial discourse regarded the native scholar, not unlike the native storyteller, as a repository of vernacular knowledge adept in indigenous languages (and sometimes an accomplished translator), with access to esoteric materials and communities. But this discourse did not recognize the native scholar as a sophisticated analyst. Analysis was, by and large, assumed to be the prerogative of the European patron. This subordinated perception in the discourse limited the salary and professional recognition for native scholars employed in the colonial government. For these scholars, government employment also meant obeying service rules and not criticizing the colonial government or its officials. Yet the astounding range of writings of the government-employed Tamil Brahman scholar Pandit S. M. Natesa Sastri (1859-1906), who was hailed as a native scholar, shows that despite all the attempts of the colonial government to subordinate Indian scholars, it could never rein in their creative selves. I show that Natesa Sastri's facets as a prolific epigraphist, folklorist, and novelist make him a kaleidoscopic author who could contest political power through the power of his imagination. When we see how Adeline Georgiana Kingscote, a racist penny novelist (who had lived in India as the wife of a British colonel), plagiarized and published Natesa Sastri's stories and then gratuitously named him a mere co-collector, the veil of collaboration falls. The irony of the construct of "native scholar" is exposed. But kaleidoscopic authorship offers more than a critique of the 
idea of "native scholar"; it also allows us to see how justice can be achieved through narrative. Natesa Sastri's outspoken criticism of discrimination in colonial service resulted in his being denied deserved promotions and salaries commensurate with his experience and erudition. He sets right this wrong in his autobiographical novel Dinadayalu, which illustrates the poetics of Indian storytelling entangled in empire. The play of self across Natesa Sastri's writings - his vivid descriptions, remembrances, interpretations, and insider critiques-dismantles imperial exclusiveness in the arts of recollection and record.

\section{Sovereignty}

Audacious narration indicates and generates sovereign spaces. The sovereignty of raconteurs, however, is not the Hobbesian sovereignty that measures the state's exercise of absolute territorial authority over a body politic. Nor is it the same as the concept that Michel Foucault and Giorgio Agamben discuss. State sovereignty, Foucault argues, expresses itself in the surveillance and bio-discipline of human bodies. Agamben's sovereign state can be brutal. It carves out a "state of exception"; it transgresses, even transcends law and determines who has the right to possess rights. ${ }^{25}$ The state structures that these thinkers critique are driven by a conceptualization that likens the sovereign to an omnipotent (Christian) god and the state to an unassailable panoptic authority. In the contexts of both precolonial and colonial India, such a view already runs into problems. Numerous studies of land and rulership in precolonial South Asia show that grammars of sovereignty were textured and context sensitive. Sometimes sovereignty was shared or brokered among many unequal centers of power around a major ruler, sometimes multiple rulers: in the late sixteenth and seventeenth centuries, the kings of Vijayanagara shared political power with a large number of local chiefs and administrative power with merchants who collected taxes on their behalf. ${ }^{26}$ When the thirteenth-century king of the Kakatiya kingdom (today in Telangana) presented ritual insignia to a powerful subordinate to "share the substance of his sovereignty," ${ }^{27}$ he was engaging in the customary practice of displaying and distributing sovereignty through ritual and aesthetic idioms. In early Hindu political theology, sovereignty is shared by deities and rulers: if the deity was the timeless sovereign, the ruler was the temporal potentate. In other political theologies, deified sovereignty comes from the deity's fluid power to bless on the one hand and to harm on the other, creating relations of power that vary across thresholds of life. ${ }^{28}$ Then there are monasteries, themselves empowered by landholdings and shastric knowledge, which often 
mediate divine and human power relations and transactions. In Sufi imagination, sovereignty is explored as a power that flows between the Almighty, the beloved, and the exalted saint, a dynamic that allows for the teasing out of human predicaments and for the fashioning of the self. ${ }^{29}$ The oral traditions of the Meo Muslim community from Rajasthan record perspectives that counter centuries of oppressive regimes and state-sanctioned histories that portray the Meo as criminals. Through epics and ballads in the Mewati language, Meos create and claim a cultural sovereignty for themselves that sustains their ethnic identity and inspires their resistance to hegemonic power. ${ }^{30}$ Thus India, indeed all of South Asia, was always a field of multiple, linked, competing, and fragmented political and ritual sovereignties.

The nineteenth century spawned a new complexity in imaginings of sovereignty as the colonial government began to propagate the idea of the British monarch as a benevolent supreme ruler for the colony. The idea could not hold on to its monolithic grandiosity. Milinda Banerjee shows how in Bengal and in the princely states of Cooch Behar and Tripura, hybrid sovereign figures emerged in response to the colonial assumption of absolute power. These figures, who ranged from princely elites and Hindu and Muslim nationalists to martial peasants, drew on models of "divine, human, and messianic kingship" available in European, Christian, Indic, and Islamic registers to assert countervailing power and authority. ${ }^{31}$ Banerjee's work reinforces the point that European models of sovereignty, with their own political and symbolic machinery, could never be merely replicated or sustained in the colonial state. Nor were these models invariably considered desirable. The goal of the Gandhian satyagrahi (the truth-striving warrior), as Ajay Skaria shows, is to "refuse both subordination to and exercise of sovereign power," a sovereign power that is organized on the Enlightenment principle of autonomy. ${ }^{32}$ Aided by other means, the colonial state made a directed effort to claim and consolidate sovereignty over India after the shocks of the 1857-58 Uprising. It began to map and measure land, native bodies, and customs and practices, and in so doing become an empire of knowledge-what Nicholas Dirks calls an "ethnographic state." 33

Yet audacious narrations command an epistemic sovereignty, which shows that the "ethnographic state" could not become sovereign. If part of the empire's claim to power lies in its pretense to omniscience, audacious raconteurs - who own and control indigenous narrative space-challenge this power, even revoke it. Their narrations index spaces that the colonizer is unable to usurp. The raconteurs demonstrate that colonial knowledge about India was hollow because it tried to erase what could not be erased: an ethos of oral culture, ties of kinship, and varieties of past-consciousness; in short, 
the everydayness of everyday life. Their sovereignty does not arise from a Kantian moral autonomy that is propelled by a free and rational will and by self-legislation. ${ }^{34}$ It comes instead from the sharing of an ethical space of being and belonging. In the midst of everyday life and its relationships, accountable to love and other emotions, guided by this - and otherworldly beings like gods and fairies-audacious raconteurs are symbiotically sovereign. As we remember with Lamming "that acre of ground," the notion of an atomistic Kantian sovereignty itself stands questioned.

The web of interconnections is contextual and particular to each raconteur. Anna Liberata de Souza's epistemic sovereignty derives from her clarity about what mattered to her (her children, her parents, her grandmother, her oral stories) - and what mattered was something that the modernity of colonialism could not give or take away. Ramaswami Raju's lotus-like sovereignty stems from a faith-in Hindu spirituality and, more important, in transnational human values - that allows him to stand outside the colonial episteme and critique it. M. N. Venkataswami’s subjective lens displays a sovereignty of stance which insists that relationships, not vacant objectivity, make history, stories and songs, and even business tangible. Finally, Natesa Sastri's kaleidoscopic authorial self, which makes him sovereign in colonial disciplines, is inspired, and complicated, by his loyalty to his family, and by his passion for Tamil landscapes of history and culture. These symbiotic connections and callings make sovereignty, as Banerjee puts it, "something which everyone can aspire for." 35

\section{Ethnographic Turns}

The figure of the audacious raconteur does not merely hover in an archive. It suffuses everyday life. This book, which began in a geographically scattered colonial-era archive, took a serendipitous ethnographic turn that brought me back to contemporary India. Never have I conducted ethnographic research that was this tantalizing. Deliberate searches, a haphazard pursuit of gut feelings and stray leads, fortuitous meetings with total strangers who shared an interest in the colonial past are all part of the research for this book. Through shoe leather and sheer luck, I discovered, over years, the families of Ramaswami Raju and Natesa Sastri in Chennai and M. N. Venkataswami in Hyderabad. Most families did not have copies of all the books written by their author ancestors. As I began to interact with these families, writings from a hundred years ago came alive in fresh ways for the families and for me. I learned how the autobiographical overtones in Natesa Sastri's novel resonated in his grandson's life, how Ramaswami Raju’s dramatic poem was 
inspired by his mystical experience, and how Venkataswami's mother, long dead, is even today a living presence that appears to help the family in times of need.

As I recount in the pages of this book the journey of my search for living families and material traces, a meta-commentary on ethnography as a form of narrative ethics unfolds, and unfolds in a different manner with each raconteur. Narrative ethics holds that ethical deliberation is a narrative endeavor, one that allows us to explore human predicaments through reflection, recollection, and retelling. Linguistically and culturally mediated and conditioned, interwoven with material things, narrative always expresses a relation to something larger than itself. Some themes especially illustrate the "narrative ethics" in this book. First, although I most explicitly develop a "sense reading" of Anna Liberata de Souza in order to discover the terms on which she may have understood herself and negotiated the colonial world she lived in, sense reading informs my interpretation of all the raconteurs in this book. Indeed, as research encounters gaps and silences or ambivalences, the hypothetical or the intuitive assumes greater ethical significance in one's method; the turn to "sensing" possible readings is inevitable and calls for an acknowledgment of limitations, chance, and failure in the research process. Second, when research occurs over a long stretch of time, as it did for this book, one sees things differently, hears new inflections, and asks fresh questions. This book narrates the arc of this change. Third, drawn as I have been into the narrative worlds of "my" raconteurs, I agree with Adam Newton, who observes that "one faces a text as one might face a person, having to confront the claims raised by that very immediacy, immediacy of contact, not of meaning." ${ }^{36}$ Working between the vivacious voices of an archive and the aspirations of living persons, however, I have had to ask: What would a face-to-face connection really mean in this context where texts intersect with lives? What exchanges invisibly occur as descendants and I co-construct stories of their ancestors, some privy to them, some privy to me? As I reconnected with the physical sites in Pune where I had grown up, Anna de Souza's story started to acquire a material immediacy in my own imagination, and I began to understand the palpable ways in which everyday artifacts and acts triggered self-recognition in descendants. The archive that I had constructed itself became a living, enduring presence, a presence that leads me to believe that the audacious raconteur is a necessary ethical and artistic figure in human experience. 